\title{
27. ENIGMATIC LOWER ALBIAN SILICOFLAGELLATES FROM ODP SITE 693: PROGENITORS OF THE ORDER SILICOFLAGELLATA? ${ }^{1}$
}

\author{
Kevin McCartney, ${ }^{2}$ Sherwood W. Wise, Jr., ${ }^{3}$ David M. Harwood, ${ }^{4}$ and Rainer Gersonde ${ }^{5}$
}

\begin{abstract}
A rich assemblage of unusual silicoflagellates has been found in Lower Cretaceous (lower Albian) sediments of Ocean Drilling Program Holes 693A and 693B (Sections 113-693A-44R-1, -44R, CC, and -693B-19X-4). The morphology of the dominant taxon shows much variability and consists of hollow branching skeletal elements without apical or basal rings. This silicoflagellate is similar in both morphology and variability to specimens hitherto assigned to Cornua aculeifera Deflandre, a taxon not previously illustrated from sediments obtained by deep sea drilling. This unusual taxon is assigned to a new silicoflagellate genus, Variramus. Two other silicoflagellate species, Variramus loperi n. sp. and Vallacerta hannai Deflandre, are also present but occur in rare abundance in these sediments. We speculate that Variramus aculeifera is the most primitive form and that it subsequently gave rise to the genera Lyramula and Cornua. Prior to the development of these two genera, Variramus loperi, a species with a polygonal symmetry of basal pikes and a distinct orientation of the skeleton, appeared and probably gave rise to the genus Vallacerta. Spine morphology, basal pike orientation, and symmetry considerations suggest a link between Variramus loperi and Vallacerta hannai.

This Lower Cretaceous assemblage of Variramus aculeifera, V. loperi, and Vallacerta hannai documented here, may represent the oldest known silicoflagellates. As such, it provides new insight into their early evolutionary development.
\end{abstract}

\section{INTRODUCTION}

An unusual discovery during ODP Leg 113 was the recovery of lower Albian diatomaceous sediments at the top of an extensive "black shale" sequence at Site 693 on the Weddell Sea margin of East Antarctica (Fig. 1). Among the well-preserved diatoms (Gersonde and Harwood, this volume; Harwood and Gersonde, this volume) and occasional radiolarians and sponge spicules in these sediments are siliceous microfossil skeletons with hollow elements that, despite the absence of a basal ring, we consider to be silicoflagellates. The dominant silicoflagellate appears to be conspecific with forms described in the literature as Cornua aculeifera Deflandre. Specimens of two additional silicoflagellate species, Vallacerta hannai Deflandre and Variramus loperi $\mathrm{n}$. sp., have also been identified. This may be the oldest silicoflagellate assemblage yet described, and thus provides new information on the early development and evolution of silicoflagellate skeletal morphology.

There have been relatively few opportunities to study Cretaceous silicoflagellates (Bukry, 1985, table 9.2), and the unusual skeletal morphologies found at Site 693 have not previously been found in deep sea drill cores. The dominant silicoflagellate in the lower Albian assemblage is highly variable in form. We document its variability by light and scanning electron microscopy (SEM) and discuss its taxonomy in relation to the poorly documented and enigmatic Cretaceous genus Cornua, to which such forms have been assigned previously. We conclude, however, that this variable form is a new genus, which we name Variramus, and that it may well constitute the ancestral stock from which the Lower Cretaceous genus Vallacerta and the Up-

\footnotetext{
${ }^{1}$ Barker, P. F., Kennett, J. P., et al., 1990. Proc. ODP, Sci. Results, 113: College Station, TX (Ocean Drilling Program).

2 Florida State University, Tallahassee, FL 32306; present address: University of Maine at Presque Isle, Presque Isle, ME 04769.

3 Department of Geology, Florida State University, Tallahassee, FL 32306.

${ }^{4}$ Byrd Polar Research Center, The Ohio State University, Columbus, OH 43210

5 Alfred Wegener Institute for Polar and Marine Research, Columbusstraße, D-2850 Bremerhaven, FRG.
}

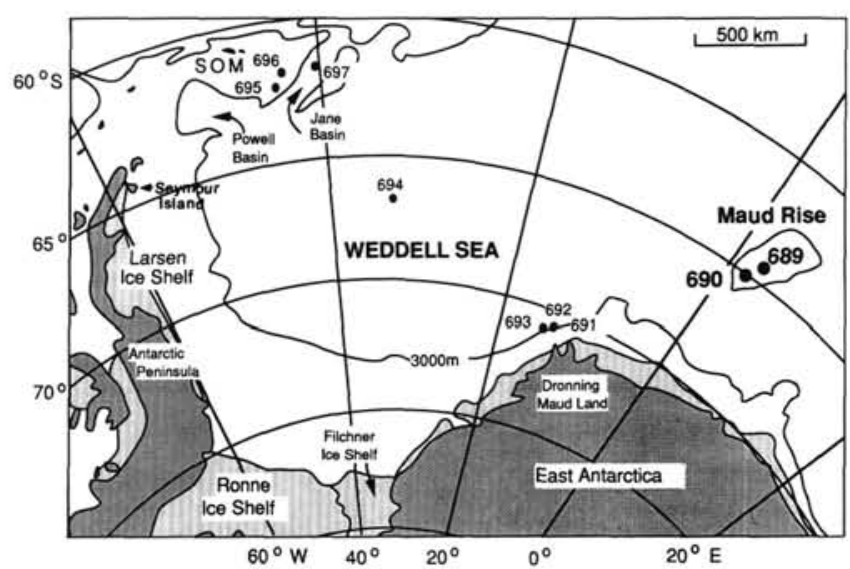

Figure 1. Map showing location of ODP Site 693 on the East Antarctic margin and other sites drilled during Ocean Drilling Project Leg 113. $\mathrm{SOM}=$ South Orkney microcontinent.

per Cretaceous genera Lyramula, Cornua, Corbisema, and Dictyocha evolved.

\section{STRATIGRAPHY}

The silicoflagellate-bearing, diatomaceous sediments were encountered beneath a prominent Cretaceous-Oligocene disconformity in two holes at Site 693 (Fig. 2). The richest biosiliceous material is described as a greenish gray, radiolarian diatomite with little terrigenous material (Sections 113-693A-44R-1 and -CC) and as a diatom claystone (base of Section 113-693B-19X4) (Barker, Kennett, et al., 1988). These intervals fall within the relatively short Lithostratigraphic Unit VI, which is dated by palynology as early Albian in age (Mohr, this volume, chapter 29). Lithostratigraphic Unit VI appears to grade downsection into an exceedingly thick $\left(1000^{+} \mathrm{m}\right)$ sequence of organic-rich Lower Cretaceous mudstones and siltstones sampled at Sites 693 and 692. At Site 693, the upper part of this black shale sequence (Lithostratigraphic Unit VII) is dated as late Aptianearly Albian in age by palynomorphs, calcareous nannofossils, 


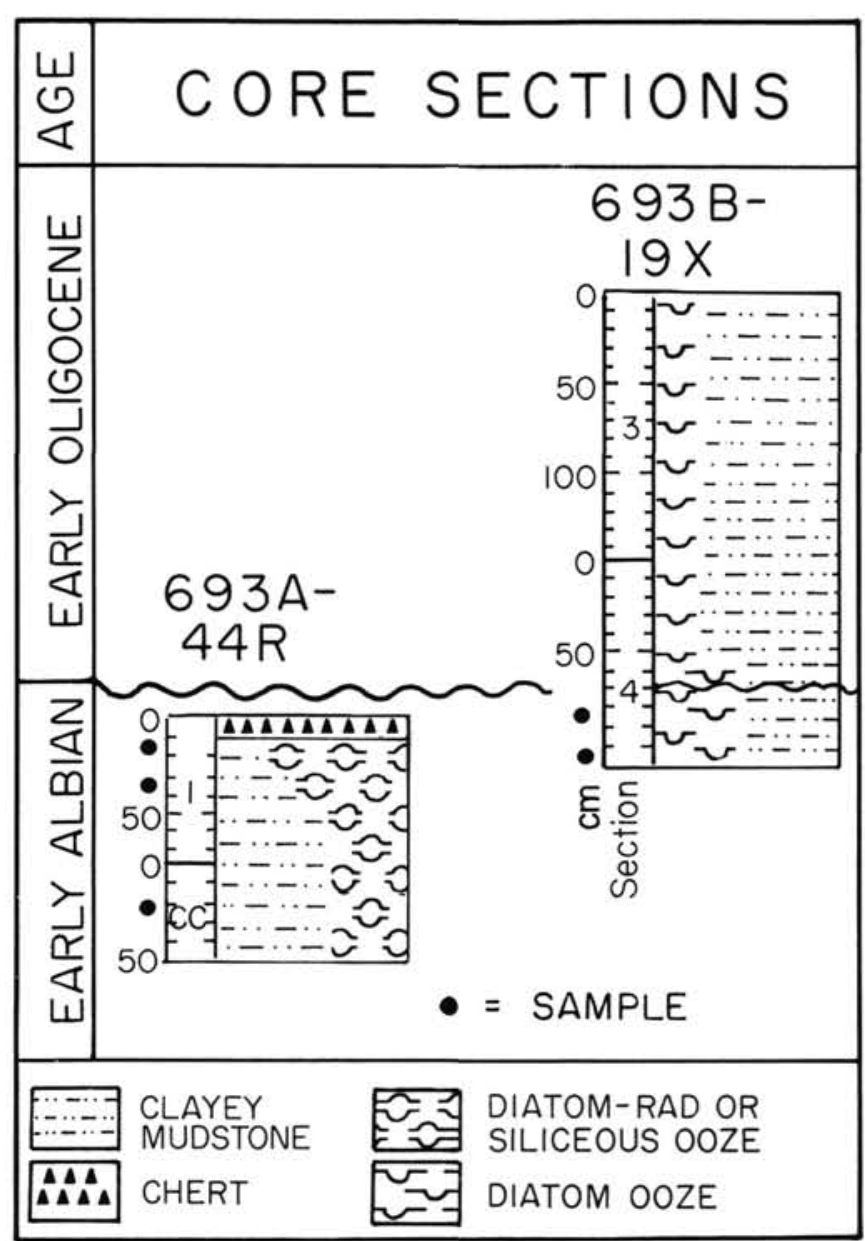

Figure 2. Location of Variramus-bearing intervals and sample location (circles) in Holes 693A and 693B, lithostratigraphy, and approximate correlation between the holes.

and foraminifers (Mohr, this volume, chapter 29; Mutterlose and Wise, this volume; Leckie, this volume).

\section{METHODS AND PREPARATION}

The silicoflagellates occur in a semilithified diatomite that required disaggregation before our examination. Samples used in this study (see also Gersonde and Harwood, this volume) were heated in an oven for several hours to dry them completely, then soaked overnight in kerosene. After soaking, the kerosene was decanted and water added to the sample. Because of the greater surface tension, the water is drawn into the sample to drive out the kerosene, thereby disaggregating the sediment (see Kummel and Raup, 1965, p. 536, for a similar method). Before sieving, the samples were washed with distilled water and then dried several times to remove the kerosene. Final washing with xylene removed any residual kerosene. The residue was then washed through a $75 \mu \mathrm{m}$ sieve and caught on a $38 \mu \mathrm{m}$ sieve. All of the resultant size fractions were examined thoroughly. The SEM photography was carried out on carbon/gold/palladium coated specimens under a JEOL 840 microscope operated at $20 \mathrm{kV}$.

\section{HISTORICAL BACKGROUND OF THE GENUS CORNUA}

Of all the fossil silicoflagellates, by far the least known are assigned to the genus Cornua Schulz. This enigmatic and sel- dom illustrated Cretaceous genus, as originally defined, has a relatively complex skeleton with pikes and spines but lacks a basal ring. Its "primitive" structure and antiquity make it an important part of discussions on the early phylogeny of the silicoflagellates. However, occurrences of Cornua are rare in deep-sea sediments. This scarcity, as well as a paucity of micrographs in the literature, has made Cornua a problematic fossil, with some workers believing that it may not be a distinct silicoflagellate group or even a silicoflagellate at all (see discussion below).

Cornua was first described by Schulz (1928) from an Upper Cretaceous (Senonian) diatomite in Westphalia, Germany. Schulz learned of these skeletons through Ortmann $(1912,1925)$, who had studied the sponge spicules in this diatomite. Schulz described one species, Cornua trifurcata, and illustrated three specimens as line drawings (Figs. 3A-C). These drawings show a skeletal morphology consisting of three intersecting bars that bifurcate at their distal ends into two spines. The drawings clearly show pikes near the points of bifurcation and a strongly symmetrical skeleton. Since this description, only two additional occurrences of $C$. trifurcata have been reported: Glezer (1959) (Fig. 3D) reported it from the Santonian-Campanian of the eastern slope of the Ural Mountains, and Bukry (1975, fig. 5; pl. 2, fig. 1) lists and illustrates it in sediments at DSDP Site 275 (Campbell Plateau, subantarctic sector of the South Pacific) that are thought to be upper Campanian to Maestrichtian in age (Hajòs, 1975; Barron, 1986; Harwood, 1988).

Hovasse (1932a, 1932b) considered Cornua to be an ebridian and described three additional species as ebridians. The species described by Hovasse do have ebridian characteristics, but except for the trigonal morphology they do not appear to have much similarity to the silicoflagellate Cornua illustrated by Schulz (1928). Subsequent silicoflagellate workers have included the Schulz species but not those of Hovasse.

Two subsequent workers (Deflandre, 1940b, 1944, 1950b; Glezer, 1959) have proposed additional silicoflagellate species for this genus. Glezer (1959) found a skeletal morphology (Fig. 3E) similar to those of Schulz, which she called $C$. poretzkiae (=C. poretzkajae in the 1970 English translation of Glezer, 1966). This taxon has weakly developed pikes and basal elements that curve forward toward the corners; if connected, they would form a corbisemid basal ring. These features led Glezer to consider $C$. poretziae as the evolutionary link to the corbi-
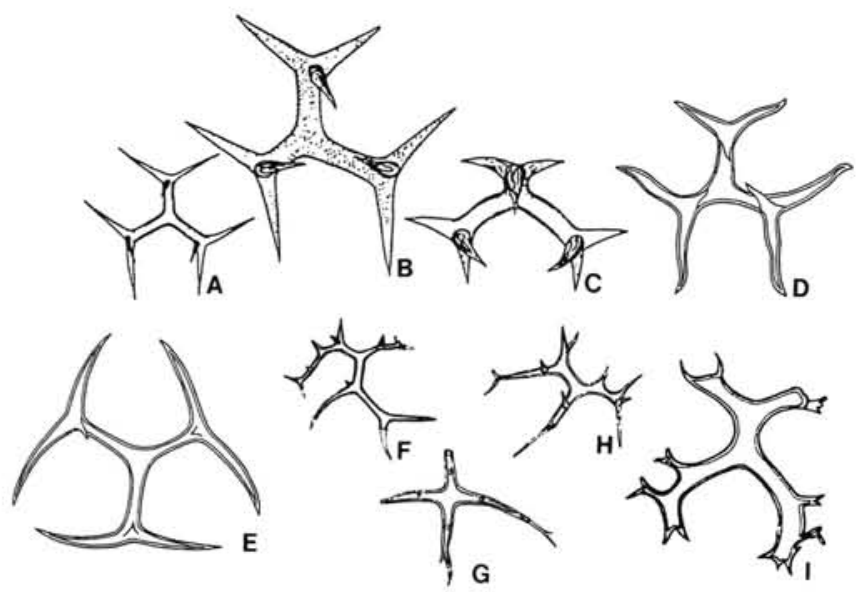

Figure 3. Illustrations of Cornua previously published in the literature: A-C. Cornua trifurcata (from Schulz, 1928); D. C. trifurcata (from Glezer, 1966); E. C. poretzkiae (from Glezer, 1959); F-H. C. aculeifera (from Deflandre, 1940b, 1944); I. C. aculeifera (from Glezer, 1966). 
semids. In Glezer (1959), Cornua poretzkiae is associated with eight other silicoflagellate taxa in an assemblage that includes C. trifurcata and species of Lyramula and Vallacerta.

Deflandre (1940a, 1944) illustrated and named, but did not describe, three specimens of Cornua aculeifera (Fig. 3F-H) from the Upper Cretaceous of California that differ considerably from the genus Cornua of Schulz by the absence of any regular symmetry. Deflandre (1950b) validated this taxon with a published description as Cornua aculeifera. Deflandre's specimens differ strongly from one another and represent a group with considerable variability of skeletal form. He emphasizes that they are remarkably plastic, and that it is difficult to find two specimens alike. Until the present study, C. aculeifera has been figured by only two other investigators. Glezer (1959, Fig. 3I) found single specimens at two of five Campanian-Santonian localities along the eastern slope of the Ural Mountains. Bukry (1975, fig. 5) lists rare specimens in samples from DSDP Site 275, and some of Bukry's illustrations from an Upper Cretaceous Arctic piston core (Bukry, 1985, pl. 9.1, figs. 4-5) resemble somewhat this taxon.

Deflandre $(1944,1950 \mathrm{~b})$ attributed his specimens to the "Diatomite de Panoche Hills, Fresno County, California (Étage de Moreno)." This refers to the Maestrichtian Moreno Shale or Moreno Formation, a 1600-1800-ft-thick unit (Wilmarth, 1938) containing some diatomaceous intervals, notably a 200 -ft-thick platy diatomaceous shale near the top called the Marca Shale Member (see McGuire, 1988, for a recent description). As the upper formation of the Chico Group, the Moreno Shale overlies the Panoche Formation, a predominately clastic unit that lacks diatomaceous sediments. Filowicz (written comm., 1988) dates the Marca Shale as uppermost Maestrichtian (nannofossil Micula murus Zone), and places the contact between the Moreno and Panoche Formations in the lower Maestrichtian (nannofossil Quadrum trifidum nannofossil Zone).

Silicoflagellates have long been known from the Moreno Formation, as Hanna (1928) named five new taxa from this unit: Corbisema geometrica, Dictyocha quadralta, Lyramula furcula, L. simplex, and Vallacerta hortonii. Mandra (1960, 1968; see also Cornell, 1972, 1974) documented these taxa from the uppermost Maestrichtian Marca Shale of the Moreno Formation, but did not mention the presence of Cornua aculeifera in these sediments. As Deflandre's $(1944,1950$ b) sample was supplied to him by Hanna, we assume that $C$. aculeifera must be quite rare in the Moreno Formation because Hanna (1928) and Mandra $(1960,1968)$ did not report it. Alternatively, these fossils could be reworked from an interval below the Marca Shale, or, the location and Maestrichtian age of Deflandre's sample are in error. It is curious that the only reported co-occurrence of $C$. aculeifera and $V$. hannai is from the sample of Deflandre (1944) and from the Site 693 lower Albian material described in this paper. We are preparing to study the materials of Deflandre (1944) to determine the relative stratigraphic position of his sample through comparative diatom and silicoflagellate analysis with Site 693 material.

Placement of Cornua among the silicoflagellates has been controversial. Some workers (Tsumura, 1963; Tappan, 1980) considered them silicoflagellates, whereas, Lipps (1970; see also Haq, 1978) believed them to be metazoan (particularly sponge) spicules. McCartney (1987) agreed that the specimens of Deflandre might be metazoan, but suggested that those illustrated by Schulz were aberrant Corbisema. This conclusion was based upon the many similarities between the Cornua of Schulz and Corbisema, and the occurrence of similar teratoid silicoflagellate morphologies in the literature. McCartney (1987) believed the absence of Cornua in open-marine sediments was additional evidence supporting this conclusion, since aberrant morphologies are less common in open waters.
In contrast to the rare occurrences of Cornua aculeifera amidst other, more abundant silicoflagellate taxa in the Upper Cretaceous of California and Russia, those at Site 693 are plentiful and accompanied by $V$. loperi and rare Vallacerta hannai. Based on the contrasting composition of these assemblages and the Early Cretaceous age assigned to the sediment, we consider the assemblage at Site 693 to be older than any others yet described from the Cretaceous. In view of the apparent antiquity of the Site 693 assemblages and because we see important differences in symmetry between the aculeiferid forms and other species assigned to the genus Cornua, we place our specimens in a new genus, Variramus (see "Systematic Paleontology," particularly before reading the "Discussion" section below).

\section{DISCUSSION}

\section{Relation to Other Silicoflagellates}

There is little doubt that the specimens of Variramus described here are silicoflagellates. The skeletons of Variramus in this study consist of simple branching skeletons of hollow elements with frequent skeletal intersections of approximately $120^{\circ}$; these are common silicoflagellate traits (see Poelchau, 1974; McCartney, 1988). These specimens also have spines and pikes that are generally similar in position and relative size to silicoflagellate morphologies. The relative diameter of the hollow space within the skeletal elements (Pl. 3, Figs. 4-5; Pl. 5, Fig. 8) is consistent with that observed in numerous silicoflagellates (Mandra and Mandra, 1972, fig. 27; Jerkovic, 1969, pl. 2; Haq, 1978, fig. 2; Perch-Nielsen, 1975, pl. 15; Hajòs, 1975, pl. 40). However, while silicoflagellates are known for their variability (McCartney and Wise, this volume), the variability found here for Variramus aculeifera is exceptional.

One possible explanation for the variability of skeletal morphologies of Variramus aculeifera found in this study is that they represent aberrant (teratoid) specimens of Dictyocha. Aberrant specimens similar to those found here are illustrated in the silicoflagellate literature (Frenguelli, 1935, pl. 1; Deflandre, 1950a, figs. 107-111; Dumitrica, 1973, pl. 12; Shitanaka, 1983, pl. 49; Harwood, 1988, pl. 23) and have been raised in cultures by Van Valkenburg $(1970,1980)$. This evidence led McCartney (1987) to conclude that Cornua might be aberrants of wellknown genera. The abundance of Variramus aculeifera in the Site 693 material and the total absence of Dictyocha and other silicoflagellates with basal rings, however, indicates that $V . a c u$ leifera is a biologically distinct taxon.

\section{Other Possible Lower Cretaceous Silicoflagellate Occurrences}

The silicoflagellates discussed here are of special interest because of their antiquity. Other Lower Cretaceous silicoflagellates have been reported in the literature, but stronger confirmation is needed before they can be considered valid. Rüst (1888, pl. 23, fig. 21), in a monograph on Cretaceous radiolarians, figured a specimen with apical and basal rings from the Gault (Albian) of Saxony (in what is now East Germany) that he referred to "Dictyocha speculum?". Deflandre (1950b) later described this as a new species, Corbisema ruestii, on the basis of Rüst's drawing. The drawing, however, is not very good, and the specimen might be a radiolarian fragment or a contaminant.

Albian "Dictyocha speculum" and "Dictyocha crux" attributed to the Thermopolis Shale of Wyoming have been reported by Klement (1963, p. 270 , addendum to "Conclusions"; see also Loeblich et al., 1968, p. 18). Klement further illustrates these taxa from a wide variety of Upper Cretaceous units from the Western Interior of the United States where he reports about two specimens per sample, most of them very well preserved as indicated by his micrographs. Most workers now place both of 
these species in the genus Distephanus, which is generally thought to originate in the late Paleogene. Distephanus speculum and $D$. crux, however, have not been reported from the more diverse and better documented Upper Cretaceous assemblages from Russia, California, and deep sea cores discussed elsewhere in this paper. Furthermore, the specimens bear strong resemblances to Distephanus from the late Miocene and Pliocene; we believe that Klement's specimens represent some kind of contamination. See Harwood (1988, figs. 23, 24), however, for Upper Cretaceous forms with an apical ring, whose taxonomic/phylogenetic position is unclear.

A few other possible earlier occurrences of Mesozoic silicoflagellates are mentioned in the literature (Tynan, 1957; Glezer, 1966), but these are not generally accepted. Thus, the occurrence of Variramus aculeifera, $V$. loperi, and Vallacerta hannai at Site 693, in the absence of any other species, may well represent the earliest known silicoflagellate assemblage.

\section{Phylogeny}

The relationship between the specimens discussed here and other silicoflagellate taxa, including Cornua, is to a large degree problematic. Nevertheless, based on the premise that our Site 693 assemblage is the most primitive known, we can speculate on a number of possible relationships. Any phylogenetic scheme we construct will necessarily differ from those of previous authors who considered various other taxa to be the most primitive. For instance, Schulz (1928) began with Paleogene representatives of Dictyocha to derive more complex Cenozoic morphologies. For the Cretaceous, Deflandre (1944, 1950b; for additional references and an excellent synopsis, see Glezer, 1966) began with the genus Corbisema Hanna to derive Vallacerta, Lyramula, and Cornua. Glezer (1966; see particularly fig. 16), on the other hand, considered Vallacerta the most primitive, and derived from it Cornua and then Corbisema (= Dictyocha triacantha var. inermis of Glezer). She then went on to draw up detailed phylogenies for the Cenozoic. Glezer probably did not consider Cornua aculeifera particularly primitive since she had encountered only two specimens, one of which was in a cored sequence that contained numerous other forms such as Vallacerta, Lyramula, and Corbisema in samples taken stratigraphically lower in the section.

In this paper we concern ourselves only with the initial stages in the development of silicoflagellate phylogeny, and refer the reader to the publications of Glezer, Deflandre, and the others cited above for subsequent development. We suggest that Variramus could have given rise to at least three lineages: Vallacerta, Lyramula, and Cornua-Corbisema (Figs. 4, 5).

The evolutionary link between Variramus and Vallacerta may possibly be through the species Variramus loperi n. sp. and Vallacerta hannai. The spines of Variramus loperi are very similar to those of Vallacerta hannai in that they lie within a gently convex plane, are long, pointed, generally straight except where they bend at the position of the pikes, and they bend in the same (apical) direction. Similarly, the pikes project in the abapical direction and are usually located about half way along the lengths of the rays. Vallacerta hannai may have developed through an expansion of the central hollow bar or trunk to form a plate or platform. One specimen (Pl. 8, Figs. 6,7) seems to have an inflated central bar, suggesting that such a mechanism was feasible. There is also the suggestion of a hollow space within the plane of the central plate where it is connected to the hollow tube at the edge of the plate (Pl. 7, Fig. 2). A reduction in pikes and a trend toward increased symmetry have led to the pentagonal Vallacerta of the Upper Cretaceous (Fig. 5).

Like Cornua, Lyramula's status as a silicoflagellate has been at times questioned. Lipps (1970) suggested that Lyramula skeletons may actually be the setae of Chaetoceras-type diatoms,

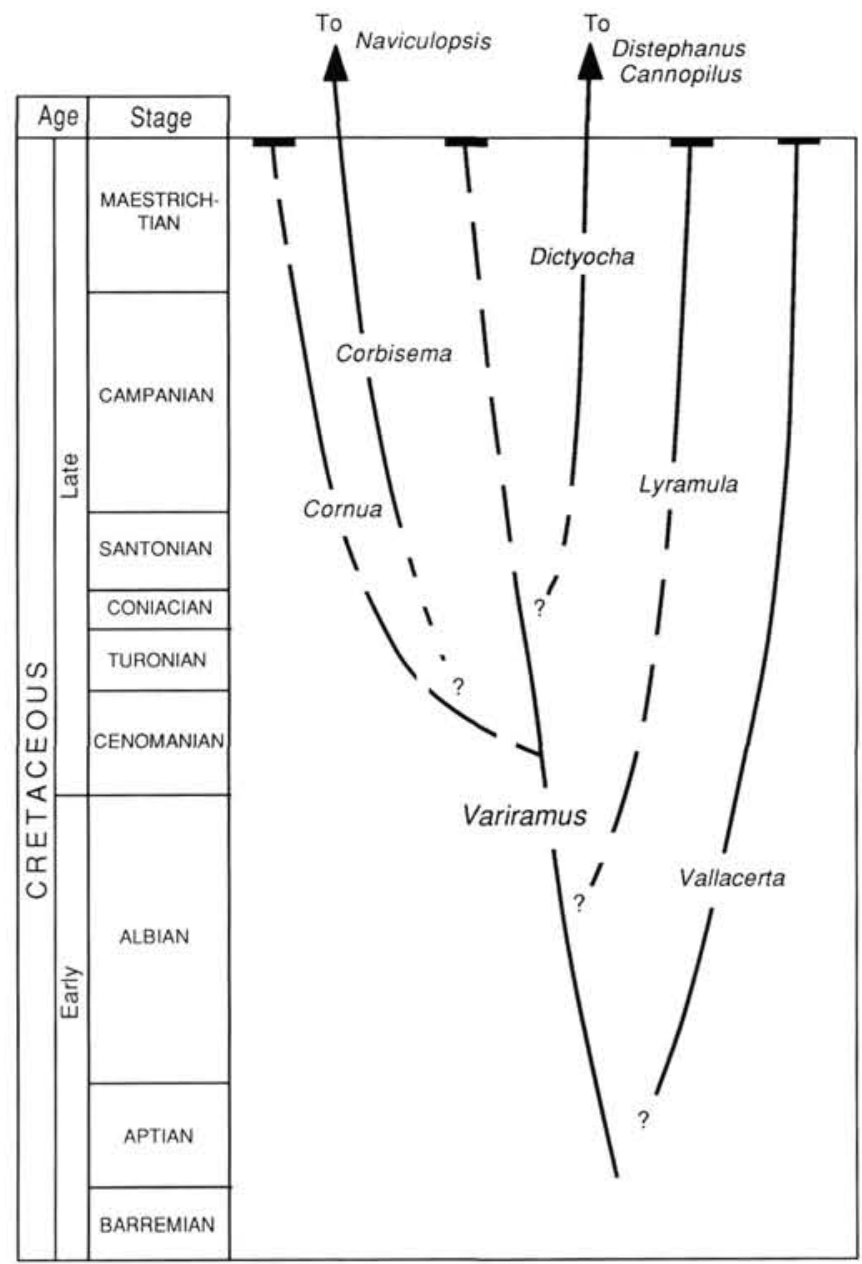

Figure 4. Cretaceous silicoflagellate phylogeny. There are no authenticated silicoflagellate occurrences between the Campanian-Santonian (where all Cretaceous genera are present) and the occurrence of Variramus and Vallacerta in the Albian.

which have a hollow construction. However, scanning electron micrographs of Lyramula (see Hajòs, 1975, pl. 40) do not support this conclusion, in that the spine is not broken as it would be if it were a diatom fragment. In addition, in the SEM Lyramula exhibits reticulate surface textures, a characteristic silicoflagellate feature (Hajòs, 1975, pl. 40; Bukry and Monechi, 1986).

Lyramula is a common, exceptionally widespread, and environmentally tolerant silicoflagellate genus (see distribution displayed by Bukry, 1985, table 9.2). As recognized by Deflandre (1950b) and Glezer (1966), however, Lyramula is highly variable in its morphology, and a number of species with two, three, and four lateral rods have been formally defined by Deflandre (1950b), Perch-Nielsen (1975), and Bukry (1981). Bukry (1985) argues that the three-pronged forms could be mutants, or phenotypic expressions for several species of Lyramula. The fourpronged species (L. burchardae) thrived in the high Arctic in environments that may have been of less than normal marine salinity. The polymorphic nature and sometimes irregular threedimensional arrays of spines displayed by this genus, however, are reminiscent of that in Variramus. It seems entirely possible that Lyramula, which was considered primitive by Glezer (1966), could have descended from Variramus by simplification and the development of a more regular structure (Fig. 5). 


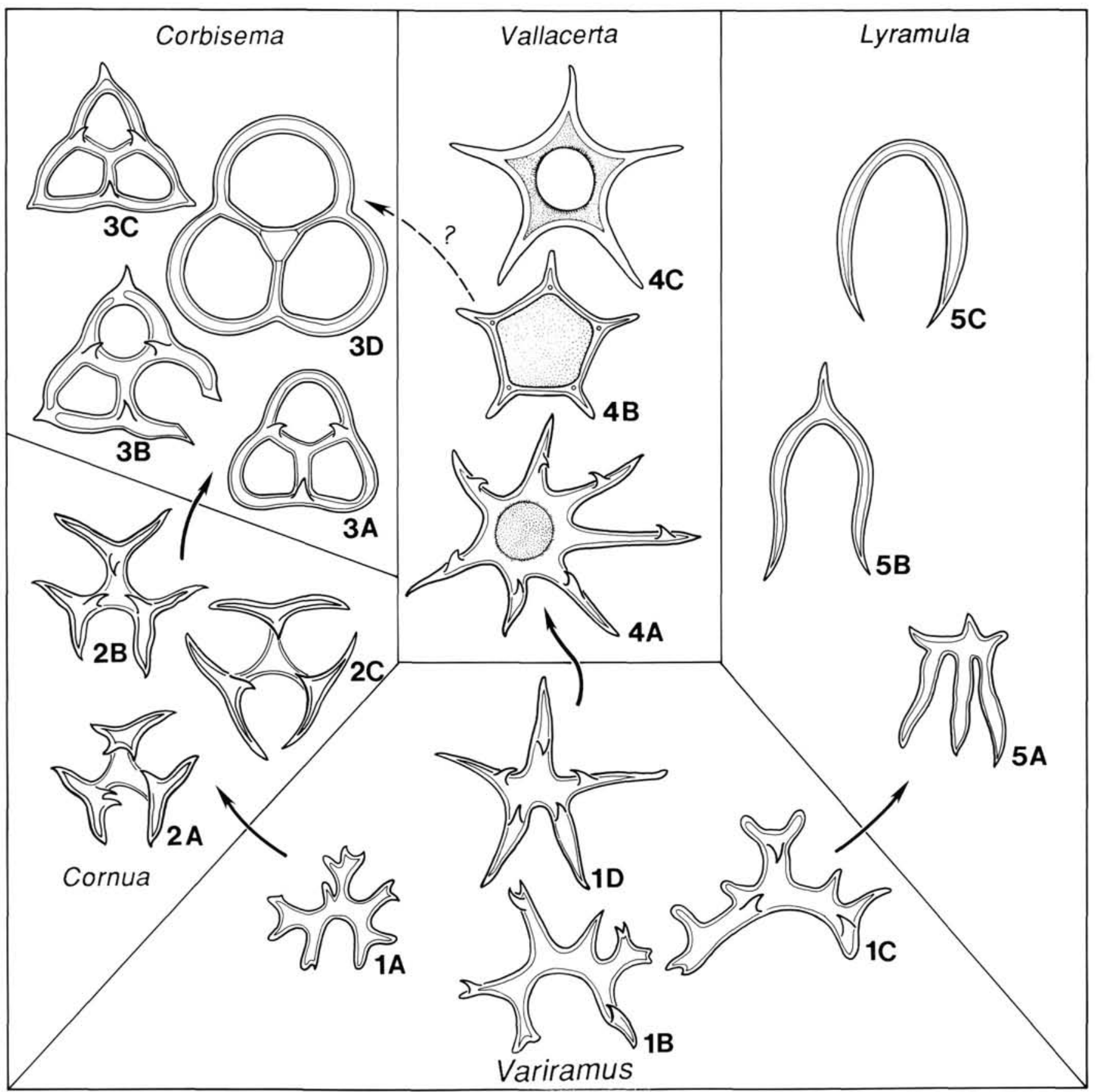

Figure 5. Illustration of Cretaceous silicoflagellate phylogeny from Figure 4, with inferences to possible evolutionary transitions. Genus Variramus is considered ancestral to the genera Cornua, Vallacerta, and Lyramula. A progressive development of silicoflagellate assemblages is implied from the base to the top of the figure. All figures are from tracings of actual specimens (abapical views except for Lyramula deflandrei, which is in lateral view). The possible evolutionary link between Vallacerta hortonii and Corbisema geometrica (arrow with question mark) is suggested by the presence in both of a plate with small basal pikes immediately adjacent on the spines or struts, respectively (see Deflandre, 1940). 1A-C. Variramus aculeifera n. comb.; 1D. V. loperi n. sp. 2A-B. Cornua trifurcata; 2C. C. poretzkiae. 3A-B. Corbisema sp.; 3C. Corbisema apiculata; 3D. C. geometrica. 4A. Vallacerta hannai; 4B. V. hortonii; 4C. V. tumidula. 5A. Lyramula deflandrei; 5B. L. furcula; 5C. L. simplex.

Similarly, the three-dimensional but much more regular construction of Cornua (Fig. 3A-E) could have been derived from Variramus by simplification with an increase in symmetry, eventually producing a regular and repeatable trilateral configuration. As Glezer (1966, fig. 16) outlined, extension of the lateral spines could then lead to a true corbisemid with a basal ring (Fig. 5). This suggestion is perhaps supported by the solid (not hollow) nature of the corners of some Corbisema specimens, where fusion of the tips of the lateral spines would have taken place (example, Fig. 5(3A); see also original photomicrograph in Harwood, 1988, fig. 23).

In summary, we view Variramus aculeifera as a legitimate silicoflagellate taxon that arose during the Early Cretaceous, before any other Cretaceous silicoflagellate. It may have given rise 
to Vallacerta hannai through an intermediate evolutionary link, V. loperi. In addition, Variramus aculeifera may be the progenitor of many other silicoflagellate genera, giving rise to Lyramula and Cornua-Corbisema through simplification of form and increase in symmetry (Fig. 5). An increase in symmetry is also evident for the younger Vallacerta species. After the advent of these other silicoflagellates, the numbers of Variramus aculeifera, $V$. loperi, and Vallacerta hannai diminished, but they may have occurred rarely in Upper Cretaceous strata as remnant taxa. This may account for the occurrence reported by Deflandre (1940, 1944, 1950b). However, if Deflandre's sample can be shown to come from the Lower Cretaceous rather than the Upper Cretaceous by diatoms present with his silicoflagellates, or by the absence of Lyramula, Dictyocha, pentagonal Vallacerta, and Corbisema in his sample, then the Late Cretaceous range of Variramus is in question and the co-occurrence of Vallacerta hannai and Variramus aculeifera could be considered biostratigraphic indicators for the Lower Cretaceous. Many of these questions of phylogeny will be resolved when silicoflagellatebearing Lower through Upper Cretaceous stratigraphic sections are recovered and studied.

\section{SYSTEMATIC PALEONTOLOGY}

Class CHRYSOPHYCEAE

Order SILICOFLAGELLATA Borgert, 1891

Genus CORNUA Schulz, 1928, emend.

\section{Type species. Cornua trifurcata Schulz, 1928.}

Emended diagnosis. The triradiate, dome-shaped apical apparatus consists of three struts that bifurcate symmetrically and curve to form the rudiments of an incomplete basal ring. The basal ring is incomplete because the tips of the bifurcations from adjacent struts do not meet. Basal pikes are present at the ends of the struts at the points of bifurcation.

Differentiation. Cornua exhibits a well-defined trigonal symmetry with respect to both the struts and their bifurcations. It is distinguished from Variramus n. gen. by this well-defined trigonal symmetry and the incomplete but symmetric rudiments of a basal ring.

Remarks. The generic definition of Cornua Schulz (1928) is based upon the species description of $C$. trifurcata, with the genotype designated by monotypy (Loeblich et al., 1968). Schulz (1928) emphasized the triradiate nature of the apical apparatus of the genotype, but other workers (Deflandre, 1944, 1950b; Glazer, 1966) included within the genus forms with crude quadrilateral symmetry or no symmetry at all (see Figs. 3A-C for illustrations of all silicoflagellate species that have been assigned to this genus). Following closely the description of Schulz's genotype, we restrict the genus Cornua to triradial symmetric forms. We assign other forms that lack a basal ring and a strict trigonal symmetry to Variramus n. gen. (see below).

\section{Genus VARIRAMUS n. genus}

Type species. Variramus aculeifera (Deflandre) 1950b, n. comb.

Diagnosis. Irregularly-shaped, hollow spinose skeletons consisting of three to six or more main branches usually not in the same plane but comprising a discernable trunk or center point. The branches in turn may be straight or slightly curved, and may bifurcate or trifurcate before terminating in points. Diameter of skeletal elements decreases from central trunk to distal spine. Trunk may be expanded. No apical or basal ring structure is present. Basal pikes in random orientation, or directed consistently in the abapical direction.

Differentiation. The genotype, Variramus aculeifera n. comb., was originally included by Deflandre $(1944,1950 \mathrm{~b})$ in the genus Cornuc Schulz (1928). Although Cornua also lacks a basal or apical ring, it is characterized by a well-defined radial symmetry, particularly by a trilateral symmetry (see discussion of the Genus Cornua above).

It is difficult to demonstrate a consistent symmetry among specimens of the genotype, Variramus aculeifera. Some incomplete specimens, if viewed from a favorable angle, may suggest a trigonal symmetry (e.g., Pl. 1, Fig. 5; Pl. 6, Fig. 5), but we consider this fortuitous and not a consistent, repeatable character. The holotype of $V$. aculeifera appears to have a rough quadrilateral or bilateral symmetry, but we have not observed any similar form which, like the holotype, shows bifurca- tions at the ray tips. Deflandre believed that the skeletons may have their origins in an apical apparatus of four branches, but quickly noted that the specimens are extremely variable, and that it is difficult to find any two alike. This is also shown by his three illustrations. Because both paratypes are highly asymmetric three-dimensional arrays, a first order symmetry is apparently not a consistent or demonstrable characteristic of this species as described by Deflandre.

The only exception to the above generalizations appears to be $V$. Ioperi $\mathrm{n}$. sp., which exhibits a polygonal symmetry of basal pikes, and whose skeletal elements lie roughly within a domed plane. The spines exhibit a consistent size and form, and the basal pikes point consistently in an abapical direction, which defines an orientation for the skeleton.

Remarks. The genus name is from the Latin, meaning "variable branches".

Variramus aculeifera (Deflandre) n. comb.

(Pls. 1-3; Pl. 4, Figs. 1,2,5-7; Pls. 5-6)

"Forme cornuoide de Dictyocha spec. ind.", Deflandre, 1940b, v. 211, p. 509 , fig. 11.

Cornua aculeifera Deflandre, 1944, v. 219, p. 464, figs. 8-9 (Nom. nud.).

Cornua aculeifera Deflandre, 1950b, v. 2, p. 114-172.

Cornua aculeifera Deflandre, Glezer, 1959, v. 10, p. 109, fig. 11. Cornua aculeifera Deflandre, Glezer, 1966, v. VII, p. 239, pl. III, fig. 1. ?Cornua sp. A, Bukry, 1985, pl. 9.1, figs. 4-5.

Remarks. Deflandre (1950b) characterized this taxon as being highly irregular, with a tendency to develop long and short spines. We note that the skeletal intersections generally consist of three elements connected by triple junctions; the angles are obtuse, and often close to $120^{\circ}$. The skeleton is usually flattened, with a bowed or dome shape producing convex (apical?) and concave (abapical?) sides. At the center of the api$\mathrm{cal}(?)$ structure is one or a series of elements that usually bifurcate at their terminations into additional elements, spines, or pikes. The terminal bifurcations may consist of two spines or a spine and a pike. If there is a pike, the pike usually occurs at a greater angle with respect to the skeletal element than the associated spine. Pikes frequently point to the abapical(?) side of the skeleton. The general structure is often similar to the apical apparatus of a four or five-sided dictyochid, but simpler and more complicated morphologies also occur. For additional comments, see "Differentiation" under the generic description.

Occurrence. The Upper Cretaceous of California (Deflandre, 1950b), Russia (Glezer, 1959, 1966), DSDP Site 275 (Bukry, 1975), possibly the Arctic (Bukry, 1981, 1985), and the Lower Cretaceous (lower Albian) of ODP Site 693 in the Weddell Sea off East Antarctica (this paper).

Comparison. The specimens illustrated by Deflandre $(1944,1950 \mathrm{~b})$ and Glezer $(1959,1966)$ (see Figs. 3F-I) resemble closely those of the present study, although Deflandre's holotype is less representative of the range of variation than the other illustrations. Deflandre's sample is cited as coming from the Moreno Formation of California, which is Maestrichtian in age. This is considerably younger than our specimens from Site 693; Glezer's samples from Russia, dated as Santonian to Campanian in age, are also younger than the Site 693 material. Thus, their biostratigraphic age may extend from the Early and through the Late Cretaceous, although much further study is needed to verify their occurrence and variability in the Upper Cretaceous localities.

Variramus loperi $\mathrm{n}$. sp.

(Pl. 4, Figs. 3, 4; Pl. 8, Figs. 4-9)

Diagnosis. A subplanar, gently domed species of Variramus that exhibits a polygonal symmetry about the basal pikes along the spines. When connected by imaginary lines, these pikes tend to form the corners of squares or pentagons, depending on the number of spines. Apical and abapical directions can be determined.

Description. This species has four or five spines that radiate from a central bar or trunk rather than a center point. However, the distal segments of the spines (portion beyond the basal pikes) exhibit a radial symmetry from an imaginary central point. Basal pikes are present at one-third to half the length of the spines, at which point the spines bend through an obtuse angle in the apical direction before terminating in a sharp point. The spines do not bifurcate and are generally straight except where they bend at the positions of the basal pikes. The pikes extend in the abapical direction. The convex apical side of the fossil is defined by the dome over the spines created by the central bar (see Pl. 4, Figs. 6, 7). 
Differentiation. The gentle apical doming of the skeleton and the consistent abapical orientation of the basal pikes defines an orientation for the skeleton that is not apparent in $V$. aculeifera. In addition, the consistent orientation of the extremities of the spines (beyond the basal pikes) denotes a radial symmetry about an imaginary center point which is also not apparent in $V$. aculeifera. In addition, the spines never bifurcate.

Remarks. The construction of the spines is similar to those of Vallacerta hannai in several respects. They both have generally straight radial spines and basal pikes at about mid-length that extend in the abapical direction. Furthermore, the spines bend at the position of the basal pikes through an obtuse angle in the apical direction, and the spines terminate without bifurcations in a point.

The specimen shown in Plate 8, Figures 6 and 7, exhibits what appears to be an expanded, hollow central bar. Further expansion of such a bar through evolution could lead to the formation of a plate or central platform similar to that present in Vallacerta. If so, then the species described here might be an evolutionary link between Variramus and Vallacerta.

This taxon is named in honor of Dr. David E. Loper, a mathematician, for his contributions toward modeling silicoflagellate skeletal morphologies (see McCartney and Loper, 1989).

Occurrence. Rare in the lower Albian of ODP Site 693, East Antarctic margin in the Weddell Sea.

Size. Holotype, $60 \mu \mathrm{m}$.

Holotype. Plate 8, Figure 5.

Isotypes. Plate 4, Figures 3, 4; Plate 8, Figures 4, 6-9.

Type locality. ODP Sample 113-693B-19X-4, 103-104 cm.

\section{Genus VALLACERTA Hanna, 1928 \\ Vallacerta hannai Deflandre, 1944}

(Pl. 7; Pl. 8, Figs. 1-3)

Vallacerta hannai Deflandre, 1944, p. 463, figs. 1-7.

Remarks. Deflandre (1944) described this species as a small (8 to 10 $\mu \mathrm{m}$ in diameter) skeleton consisting of a convex plate with seven unequal spines, which bear basal pikes at some distance along the spine. The five specimens illustrated by Deflandre do not show the symmetry expressed in most other species of Vallacerta. Other Vallacerta from the Upper Cretaceous have either lost the basal pikes or they are greatly reduced, as in V. hortonii (Mandra, 1968, figs. 11, 12; McPherson and Ling, 1973, pl. 1, figs. 8, 9; Perch-Nielsen (1975, pl. 14, figs. 5, 6). These more advanced forms also exhibit a higher degree of symmetry and a reduction in the length and numbers of spines (five being the most common).

The skeleton consists of a bowl-shaped plate without portals, but with spines that splay outward from the base of the plate. The spines tend to lie within a plane and there usually are seven of them, although variations on this number might occur. The plate is subcircular, heptagonal (Pl. 8, Fig. 1), or suboval in outline; spines aligned with the long axis of the plate tend to be larger than spines aligned with the short axis. Only the apical surface of the plate is ornamental with weakly developed granules that merge into short lines. Pikes are situated on the spines and point away from the plate, in the abapical direction. The location of the pikes along the spine is variable.

The general morphology of Vallacerta hannai bears many similarities to younger Cretaceous and Cenozoic silicoflagellates. These include the near-circular shape of the basal "ring", the dome-shaped apical structure, the relative size and distribution of the spines within a plane around the basal ring, and the presence of pikes that point away from the apical dome. Vallacerta hannai differs from other silicoflagellates outside the genus by the presence of a solid apical structure without portals. The presence of basal pikes along the spines rather than on the basal ring is shared only by Variramus loperi (see above), although basal pikes occur in Vallacerta hortonii at the junction of the spines with the apical plates, and in Corbisema lateradiata along the lateral rods (McPherson and Ling, 1973).

\section{ACKNOWLEDGMENTS}

This paper was significantly improved by helpful reviews by Dr. David Bukry (USGS, Menlo Park) and H. Y. (Jim) Ling (University of Northern Illinois) plus additional comments by Dr. James P. Kennett and the ODP Editorial Staff. We are pleased to acknowledge Dennis Cassidy and the resources of the
Antarctic Research Facility and Reference Library, which he made available to us. Professor Helen Tappan (UCLA) provided necessary pieces of literature, and Mr. Mark Filewicz (Union Oil Co.) kindly provided unpublished stratigraphic information and references on California Cretaceous sections. Technical assistance was kindly provided by Gerald Arnold, Cynthia Wise, Steven Knuttle, Kim Riddle, and Darren Millman. Laboratory support and/or equipment were provided by NSF Grant DPP8414268 , JOI/USSAC funds, and the Amoco Foundation.

\section{REFERENCES}

Barker, P. F., Kennett, J. P., et al., 1988. Proc. ODP, Init. Repts., 113: College Station, TX (Ocean Drilling Program).

Barron, J. A., 1986. Diatoms from the CEASAR-6 core, Alpha Ridge, Arctic Ocean. In Jackson, H. R., Mudie, P. J., and Blasco, S. M. (Eds.), Initial Geological Report on CESAR -the Canadian Expedition to Study the Alpha Ridge, Arctic Ocean. Geol. Surv. Can. Pap., 84:137-148.

Bukry, D., 1975. Silicoflagellate and coccolith stratigraphy, Deep Sea Drilling Project, Leg 29. In Kennett, J. P., Houtz, R. E., et al., Init. Repts. DSDP, 29: Washington (U.S. Govt. Printing Office), 845872. $1: 57-63$.

1981. Cretaceous Arctic silicoflagellates. Geo-Marine Lett., 1985. Correlation of Late Cretaceous Arctic silicoflagellates from Alpha Ridge. In Jackson, H. R., Mudie, P. J., and Blasco, S. M. (Eds.), Initial Geological Report on CESAR -the Canadian Expedition to Study the Alpha Ridge, Arctic Ocean. Geol. Surv. Can. Pap., 84:125-135.

Bukry, D., and Monechi, S., 1985. Late Cenozoic silicoflagellates from the northwest Pacific, Deep Sea Drilling Project Leg 86: paleotemperature trends and texture classification. In Heath, G. R., Burckle, L. H., et al., Init. Repts. DSDP, 86: Washington (U.S. Govt. Printing Office), $367-397$.

Cornell, W. C., 1972. Chrysomonad cysts and silicoflagellates from the Marca Shale Member, Moreno Formation (Maestrichtian), Fresno County, California [Ph. D. dissert.]. Univ. California, Los Angeles. 1974. Maastrichtian silicoflagellates of the Great Valley, California. Geoscience and Man, 9:37-44.

Deflandre, G., 1940a. Sur les affinités et la phylogenése du genre Vallacerta, Silicoflagellidée du Crétacé supérieur. C. R. Acad. Sci. Paris, 211:445-448.

1940b. L'origine phylogénétique des Lyramula et l'évolution des Silicoflagellidés. C. R. Acad. Sci. Paris, 211:508-510.

1944. Remarques sur l'évolution des Silicoflagellidés, à propos des deux espèces crétaciques nouvelles. C. R. Acad. Sci. Paris, 219:463-465.

1950a. Contribution à l'étude des Silicoflagellidés actuels et fossiles. Microscopie, 2:72-108.

1950b. Contribution a l'étude des Silicoflagellidés actuels et fossiles (Suite). Microscopie, 2:114-172.

Dumitrica, P., 1973. Miocene and Quaternary silicoflagellates from the Mediterranean Sea. In Ryan, W. B. F., Hsü, K. J., et al., Init. Repts. DSDP, 13: Washington (U.S. Govt Printing Office), 902-939.

Frenguelli, J., 1935. Variaciones de Dictyocha fibula en el Golfo de San Matas (Patagonia septentrional). An. Mus. Argentino Cienc. Nat. "Bernardino Rivadavia", 38:265-281.

Glezer, Z. I., 1959. Nekotorye novye dannye o semeystve Vallacertaceae Deflandre (Silicoflagellatae). Vses. Nauchno-Issledov. Geol. Inst. (VSEGEI), 10:103-113.

1966. Silicoflagellatophyceae: In Flora Plantarum Cryptogammarum USSR, Akad. Sci. USSR, Institutun Botanicum, 7:1363.

Hajòs, M., 1975. Late Cretaceous Archaeomonadaceae, Diatomaceae, and Silicoflagellatae from the South Pacific Ocean, Deep Sea Drilling Project, Leg 29, Site 275. In Kennett, J. P., Houtz, R. E., et al., Init. Repts. DSDP, 29: Washington (U. S. Govt. Printing Office), 913-1009.

Hanna, G. H., 1928. Silicoflagellata from the Cretaceous of California. J. Paleontol., 1:259-263.

Haq, B. U., 1978. Silicoflagellates and ebridians. In Haq, B. U., and Boersma, A. (Eds.), Introduction to Marine Micropaleontology: New York (Elsevier), 267-275. 
Harwood, D. M., 1988. Upper Cretaceous and lower Paleocene diatom and silicoflagellate biostratigraphy of Seymour Island, eastern Antarctic Peninsula. Geol. Soc. Am. Mem., 169:55-129.

Hovasse, R., 1932a. Seconde note sur les Ebriacées. Soc. Zool. Fr., Bull., 57:278-283.

1932b. Troisième note sur les Ebriacées. Soc. Zool. Fr., Bull., 57: 457-476.

Jerkovic, L., 1969. Les nouvelles recherches de la superficie du squelette des silicoflagellidés. Fodisnjak, Ann. Inst. Biol., Univ. Sarajevo, 22: 129-175.

Klement, K. W., 1963. Occurrence of Dictyocha (Silicoflagellates) in the Upper Cretaceous of Wyoming and Colorado. J. Paleontol. 37:268 270.

Kummel, B., and Raup, D., 1965. Handbook of Paleontological Techniques. San Francisco (W. H. Freeman and Co.).

Lipps, J. H., 1970. Ecology and evolution of silicoflagellates. In Yochelson, E. L. (Ed.), Proc. N. Am. Paleontol. Conv., Chicago, 2: 965-993.

Loeblich, A. R., III, Loeblich, L. A., Tappan, H., and Loeblich, A. R., Jr., 1968. Annotated Index of Fossil and Recent Silicoflagellates and Ebridians with Descriptions and Illustrations of Validly Proposed Taxa. Geol. Soc. Am. Mem., 106:1-319.

Mandra, Y. T., 1960. Fossil silicoflagellates from California, U.S.A. Copenhagen Internat. Geol. Congress, XXI Session Norden, Part 6, Proc. Sec. 6, Pre-Quaternary Micropaleontol., 77-89.

1968. Silicoflagellates from the Cretaceous, Eocene, and Miocene of California, U.S.A. Proc. Calif. Acad. Sci., 36:231-277.

Mandra, Y. T., and Mandra, H., 1972. Paleoecology and taxonomy of silicoflagellates from an upper Miocene diatomite near San Felipe, Baja California, Mexico. Calif. Acad. Sci., Occas. Pap., 99.

McCartney, K., 1987. Silicoflagellates, ebridians and archaeomonads. In Broadhead, T. W. (Ed.), Fossil Procaryotes and Protists: Notes for a Short Course, Paleontol. Soc., Cushman Found., Univ. Tennessee Studies in Geol., 18:146-168.

1988. Modeling silicoflagellate skeletal morphology [Ph.D. dissert.]. Florida State Univ., Tallahassee.

McCartney, K., and Loper, D. E., 1989. Optimized skeletal morphologies of silicoflagellate genera Dictyocha and Distephanus. Paleobiology, 15:283-298.

McGuire, D. J., 1988. Depositional framework of the Upper Cretaceous-Lower Tertiary Moreno Formation, Central San Joaquin Ba- sin, California. In Graham, S. (Ed.), Studies of the geology of the San Joaquin Basin: Pac. Sect. Soc. Econ. Paleontol. Mineral., 60: 173-388.

McPherson, L. M., and Ling, H. Y., 1973. Surface microstructure of selected silicoflagellates. Micropaleontology, 19:475-480.

Ortmann, P., 1912. Die Mikroskleren der Kieselspongien in Schwammgesteinen der senonen Kreide. Neues Jahrb. Mineral., 2:127-149.

, 1925. Astrophora baltica-kein Schwamm, sondern eine Wurmrohre. Z. Geschiebeforschung, 1:150-171.

Perch-Nielsen, K., 1975. Late Cretaceous to Pleistocene silicoflagellates from the southern Southwest Pacific, DSDP, Leg 29. In Kennett, J. P., Houtz, R. E., et al., Init. Repts. DSDP, 29: Washington (U.S. Govt. Printing Office), 677-721.

Poelchau, H. S., 1974. Holocene silicoflagellates of the North Pacific: Their distribution and use for paleotemperature determination [Ph.D. dissert.]. Univ, of California, San Diego.

Rüst, D., 1888. Beiträge zur Kenntnis der fossilen Radiolarien aus Gesteinen des Kreide. Palaentographica, 34:181-214.

Schulz, P., 1928. Beiträge zur Kenntnis fossiler und rezenter Silicoflagellaten. Bot. Arch., 21:225-292.

Shitanaka, M., 1983. Silicoflagellate remains in the sediments of Lake Hiruga, Fukui, Japan., Bull. Mizunami Fossil Museum, 10:171180.

Tappan, H., 1980. The Paleobiology of Plant Protists. San Francisco (W. H. Freeman and Co.).

Tsumura, K., 1963. A systematic study of Silicoflagellatae. J. Yokohama Mun. Univ. Series C-45, 146:1-84.

Tynan, E. J., 1957. Silicoflagellates of the Calvert Formation (Miocene) of Maryland. Micropaleontology, 3:127-136.

Van Valkenburg, S. D., 1970. The ultrastructure of the silicoflagellate Dictyocha fibula Ehrenberg [Ph.D. dissert.]. Univ. of Washington, Seattle.

, 1980. Silicoflagellates. In Cox (Ed.), Phytoflagellates, North Holland (Elsevier), 335-350.

Wilmarth, M. G., 1938. Lexicon of Geological Names of the United States (Including Alaska). U.S. Dept. Int. Bull. 896:1-2396.

Date of initial receipt: 27 February 1989

Date of acceptance: 21 July 1989

Ms 113B-206 

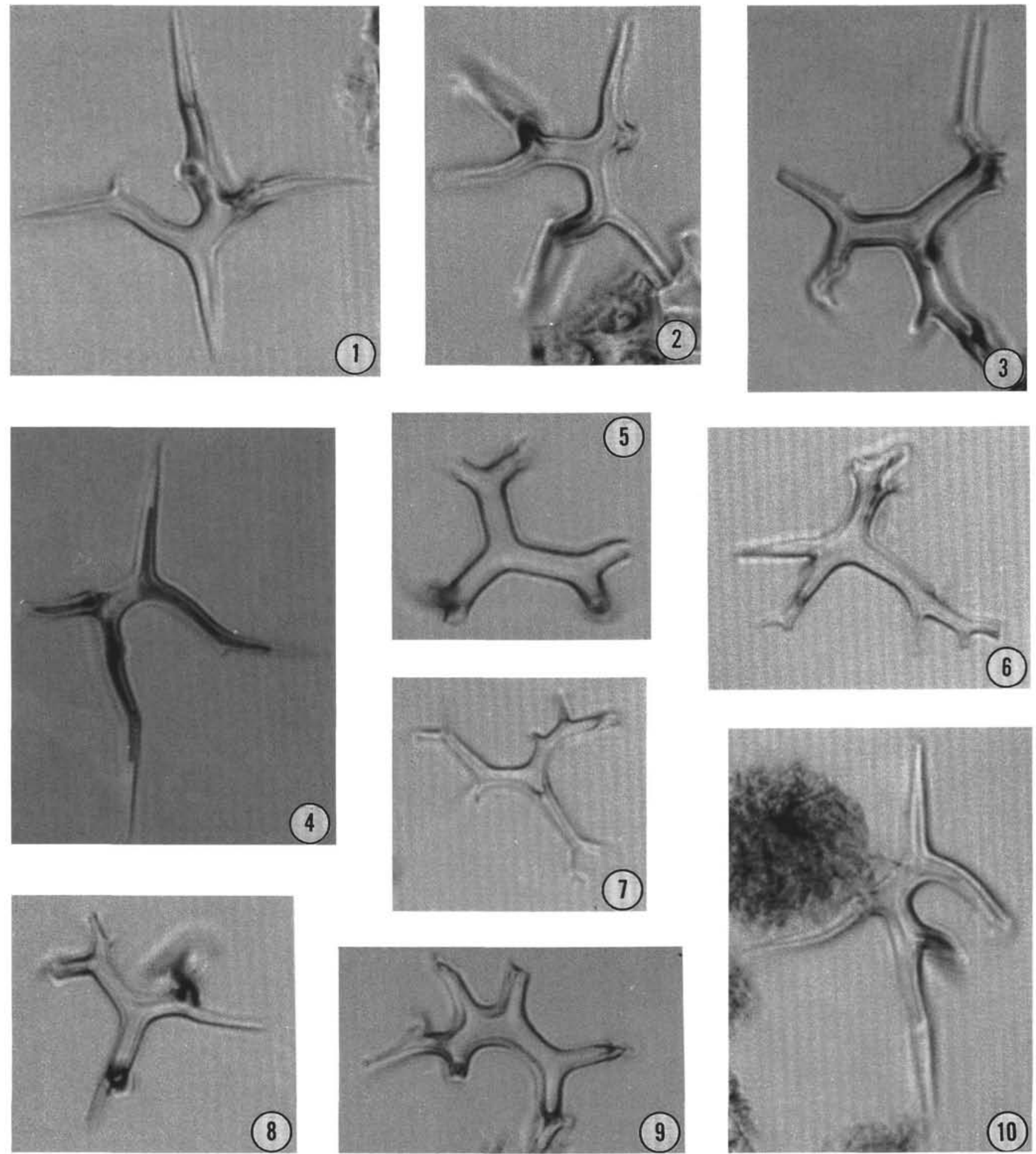

(7)

Plate 1. 1-10. Variramus aculeifera (Deflandre), Sample 113-693A-44R-1, 14-18 cm, $\times 700$.

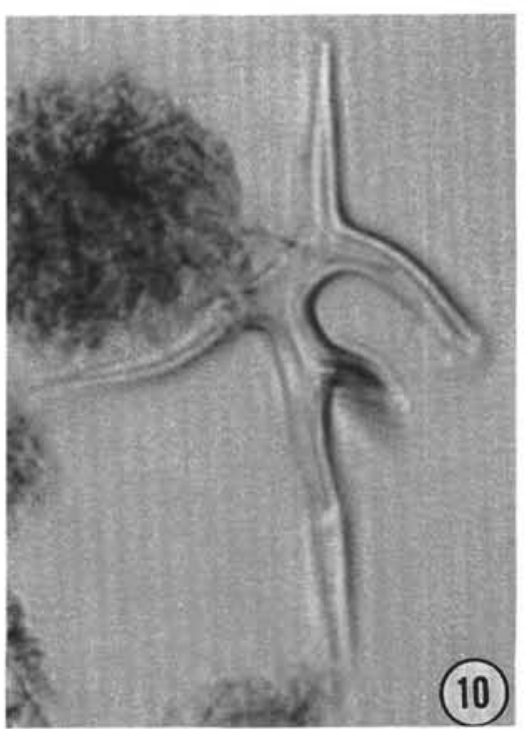



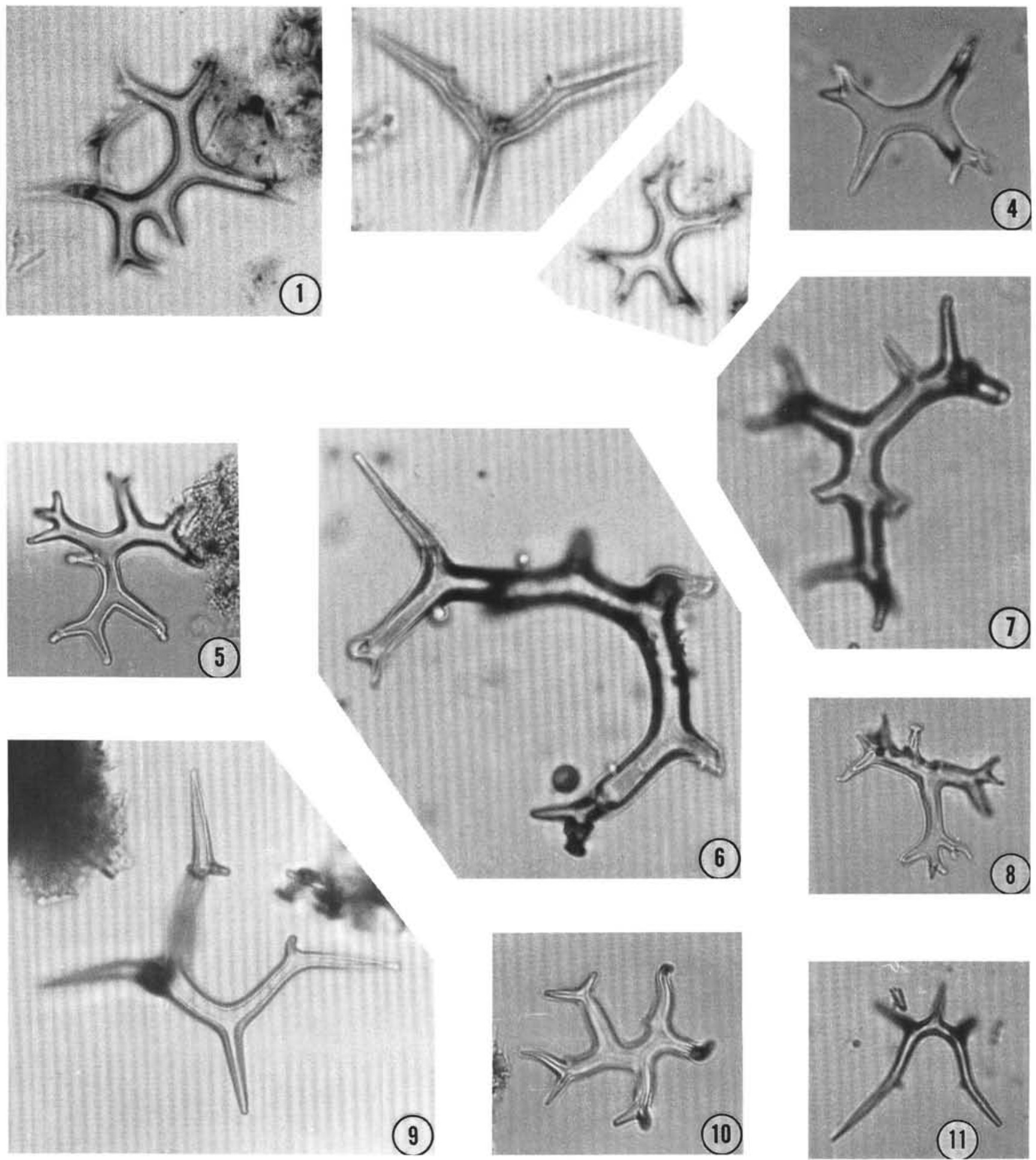

Plate 2. Variramus aculeifera (Deflandre) n. comb. 1-3. Sample 113-693B-19X-4, 105-106 cm, $\times 700$. 4-11. Sample 113-693A-44R-1, 14-18 cm, (4) $\times 800$; (5) $\times 625 ;(6,7) \times 800 ;(8) \times 575 ;(9) \times 800 ;(10,11) \times 500$. 

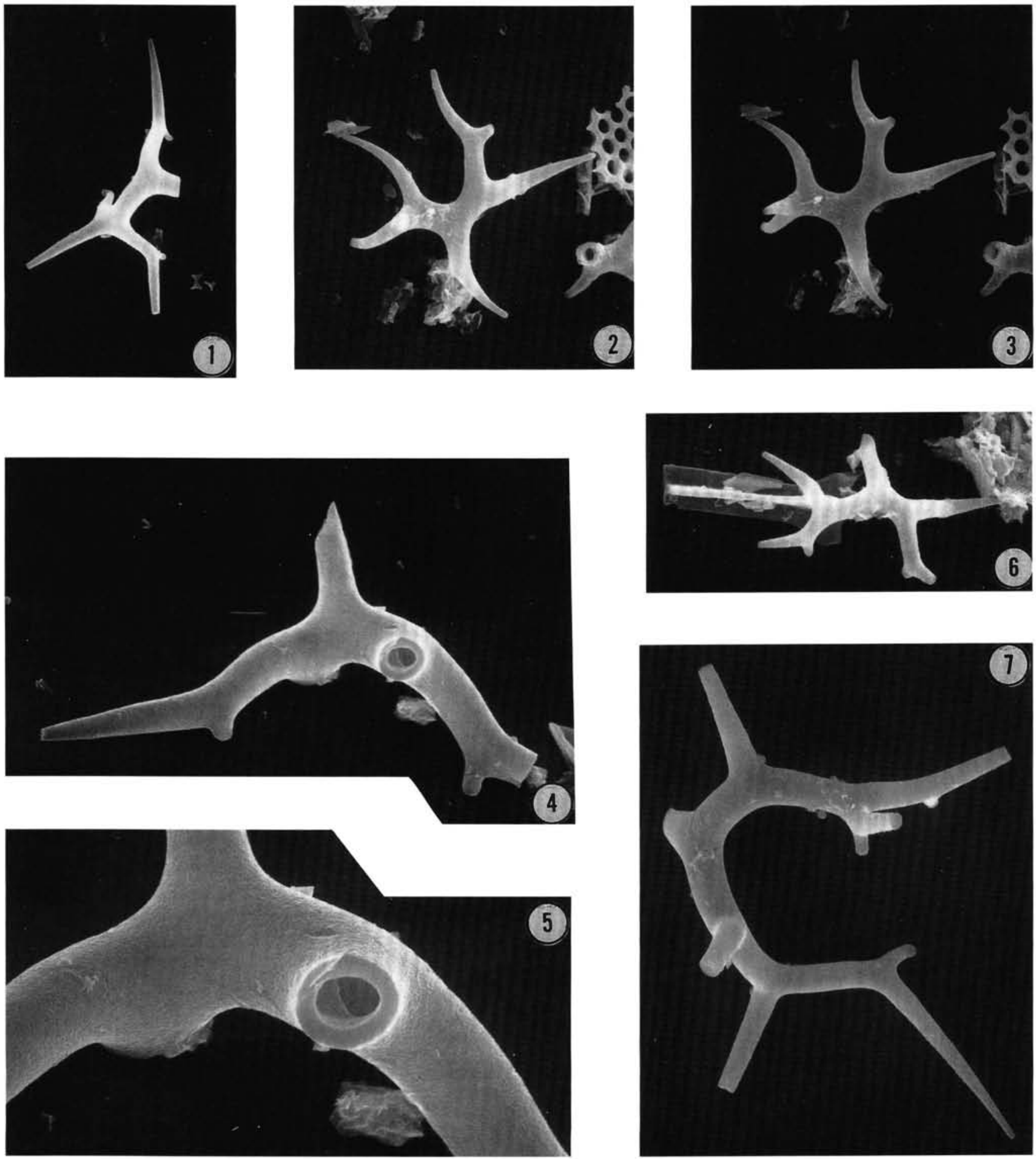

Plate 3. Variramus aculeifera (Deflandre) n. comb., Sample 113-693B-19X-4, 105-106 cm. 1. $\times 1500$. 2-3. Stereo-pair, 20 difference, $\times 1100$. 4, 5. (4) $\times 1500$; (5) $\times 3300$, enlargement of (4) showing broken surface. 6. $\times 1500$. 7. $\times 1100$. 

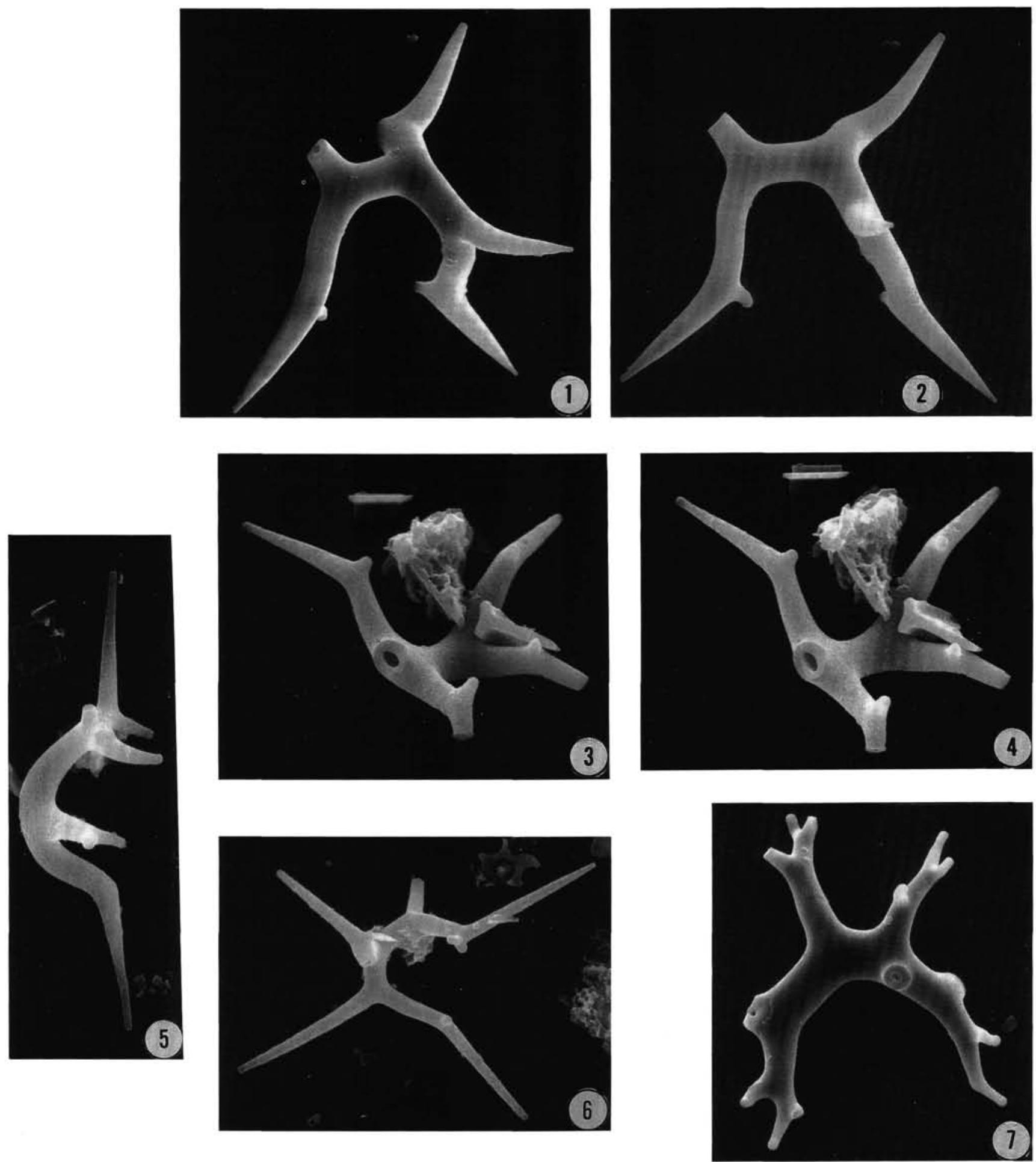

Plate 4. Sample 113-693B-19X-4, 105-106 cm. 1-2. Variramus aculeifera (Deflandre) n. comb., stereo-pair, 20 difference, $\times 1100$; 3-4. Variramus loperi $\mathrm{n}$. sp., stereo-pair, $15^{\circ}$ difference, $\times 1500$. 5-7. Variramus aculeifera $\mathrm{n}$, comb., $(5) \times 1500 ;(6) \times 1100 ;(7) \times 1100$. 

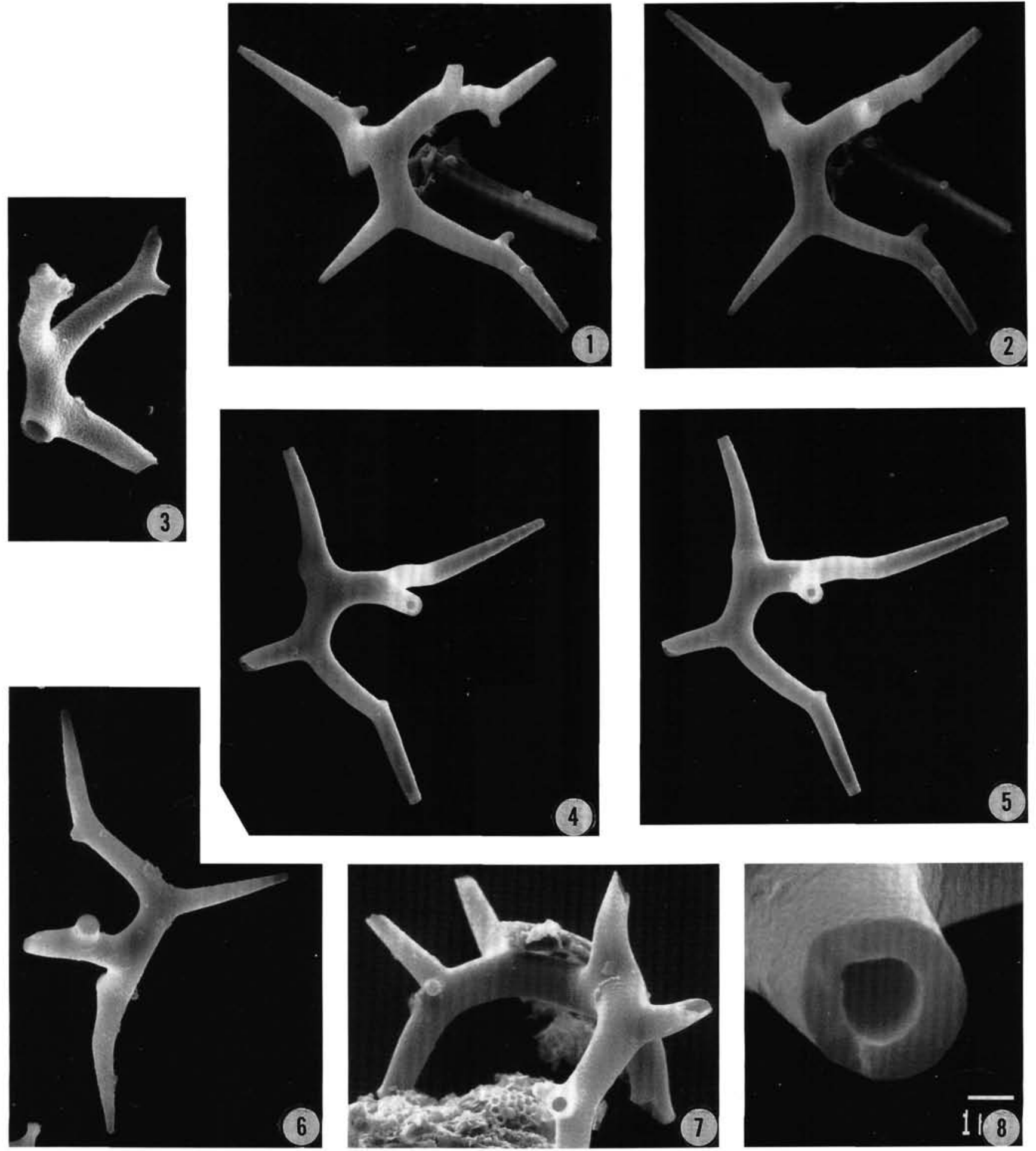

Plate 5. 1-8. Variramus aculeifera (Deflandre) n. comb., Sample $113-693 \mathrm{~A}-44 \mathrm{R}-1,14-18 \mathrm{~cm} .(1,2)$ Stereo-pair with $20^{\circ}$ difference, $\times 1100$; $(3)$ $\times 2000 ;(4,5)$ Stereo-pair with $20^{\circ}$ difference, $\times 1100 ;(6) \times 1100 ;(7) \times 1100 ;(8) \times 8000$, showing broken surface of specimen illustrated in Figures 4 , 5 above; scale bar applies to this specimen only. 

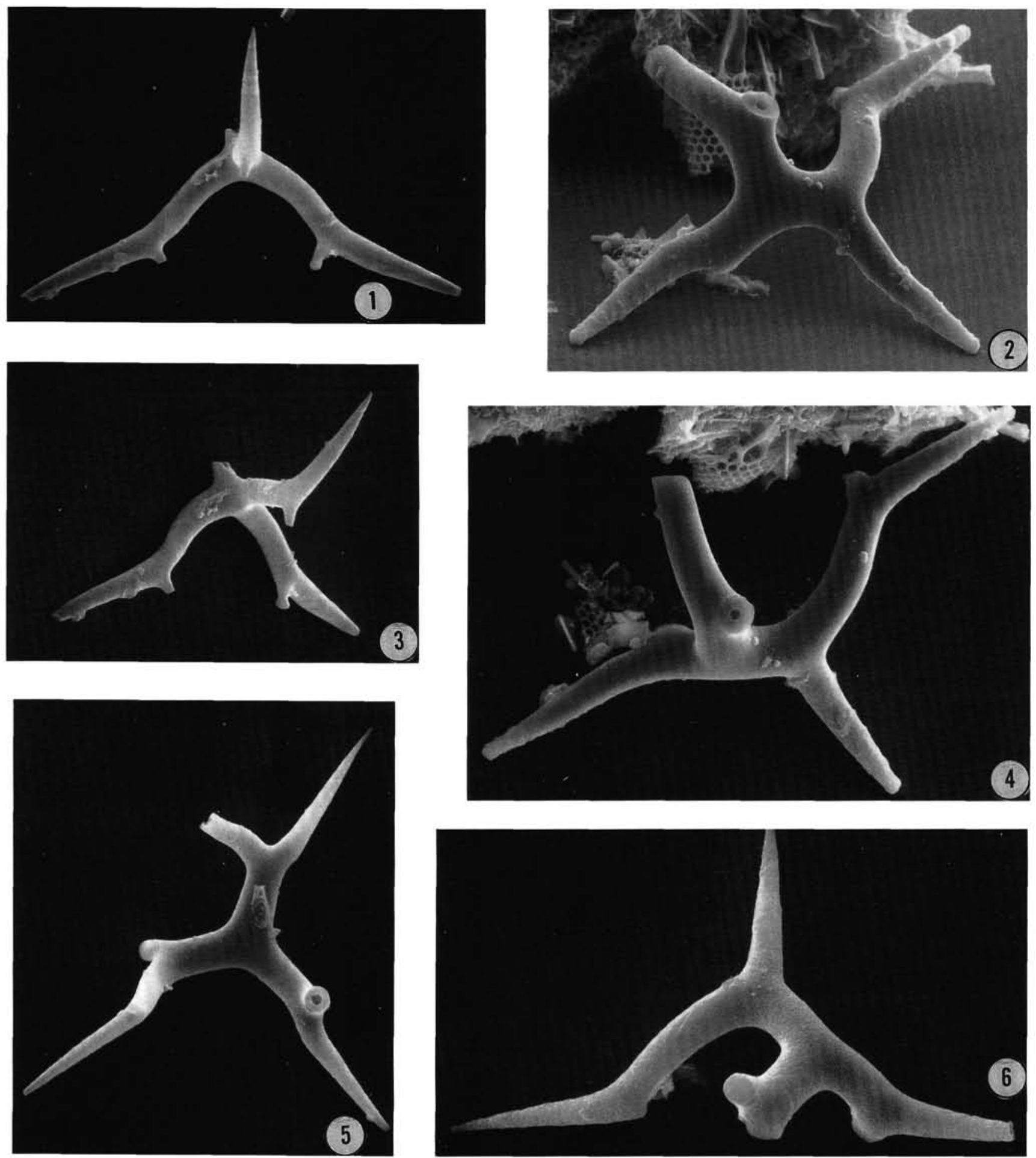

Plate 6. 1-6. Variramus aculeifera (Deflandre) n. comb., Sample 113-693A-44R-1, 14-18 cm. $(1,2)$ Same specimen, $45^{\circ}$ difference, $\times 1100 .(3,4)$ Same specimen, $50^{\circ}$ difference, $\times 1500 ;(5) \times 1100 ;(6) \times 2000$. 

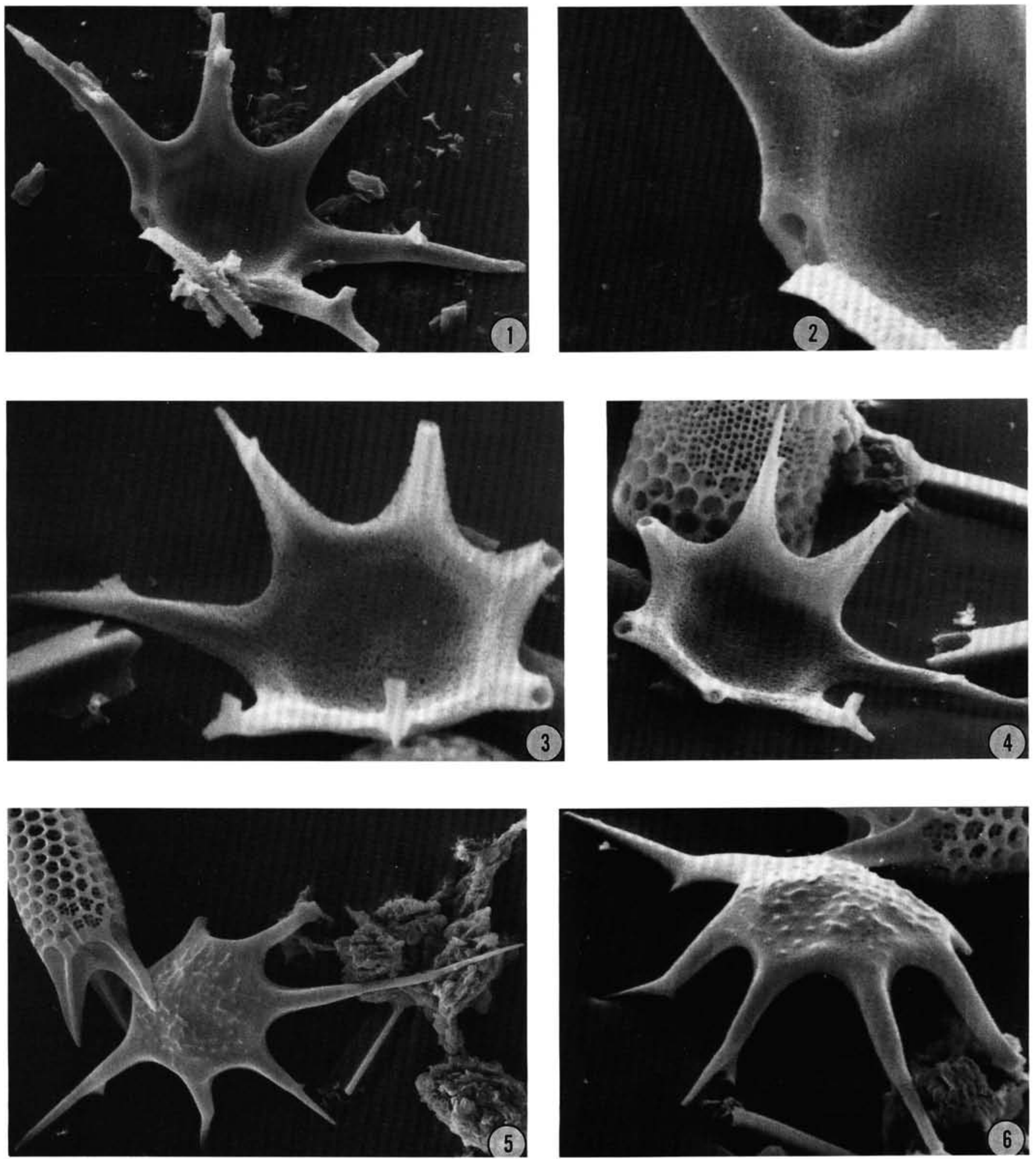

Plate 7. 1-6. Vallacerta hannai Deflandre, Sample 113-693B-19X-4, 77-78 cm., Scale bars $=10 \mu \mathrm{m}$. 

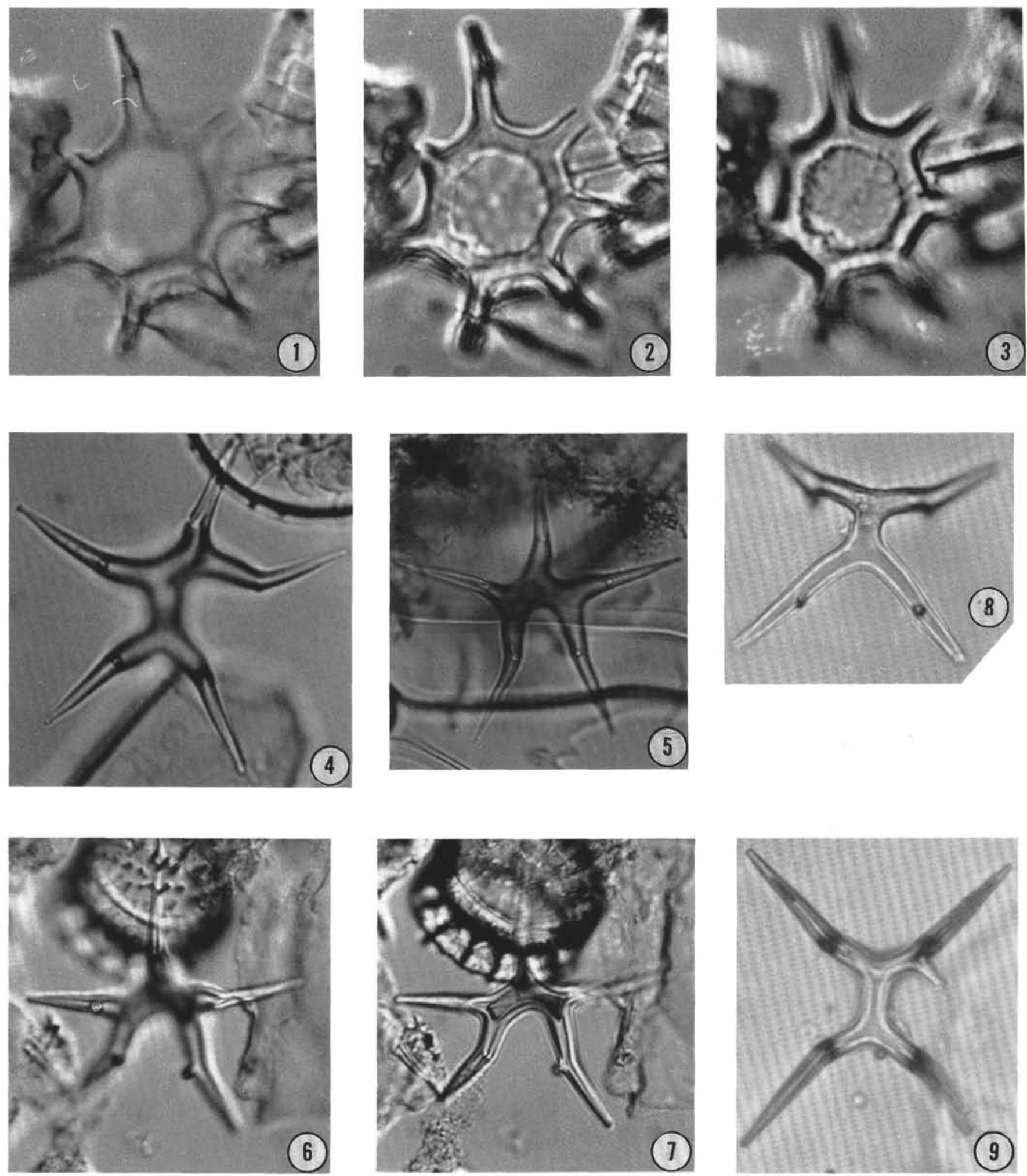

Plate 8. 1-3. Vallacerta hannai Deflandre, Sample 113-693B-19X-4, 77-78 cm, $\times 2000$. 4-9. Variramus loperi $\mathrm{n}$. sp. 4-5. Sample 113-693-19X-4, 103-104. (4) $\times 1000$; (5) holotype, $\times 750$. 6-9. Sample 113-693B-19X-4, 77-78. $(6,7)$ high and low focus respectively, $\times 750 ;(8,9) \times 800$. 